\title{
Writers develop skills through collaboration: an action research approach
}

\begin{abstract}
- Abstract
Collaborative approaches designed to increase writing productivity (amount written) as well as writing quality were implemented over a period of six months with a small group of twelve six year olds in a Primary School in Newcastle, NSW, Australia. The study demonstrated the positive nature of peer interactions with an increase in quality and productivity of writing products. The classroom teacher employed action research approaches where observations informed action which in turn was reflected upon. Some central themes emerged from this study. It was found that collaboration often meant that students shared strengths and expertise; provided encouragement and assistance as well as provided opportunities for peer tutoring.
\end{abstract}

\section{- Introduction}

"The goal of teachers to be professional problem solvers who are committed to improving both their own practice and student outcomes provides a powerful reason to practice action research” (Peterson, 1992 as cited in Mills, 2003).

Research points to the fact that quality teachers make a difference both to their students' lives and to their learning (NSW Department of Education and Training, 2003; Rowe \& Rowe, 2002). Quality teachers are therefore continually working to improve their teaching and their students' learning. This study arose from my commitment as a practising teacher to the importance of reflective practice in order to make informed decisions. My understanding of the powerful nature of reflective practice (Anderson, Herr, \& Nihlen, 1994; Dewey, 1933; Schon, 1983; Stringer, 2004) was empowering and therefore my own teaching incorporated aspects of 'active or interactive reflection’ (Grushka, Hinde McLeod, \& Reynolds, 2005; Schon, 1983).

The study, prompted by a higher degree dissertation as part of my Master of Arts in Children's Literacy and Literature, focussed on a group of 12 children. These children had previously had a year at school so had some writing instruction and were now in their second year (first class, which is generally age 6 and 7). They were part of a composite Kindergarten / First class that I taught as a full time teacher whilst doing my MA part time. The school, a large inner city school (approx 380 students), is one that has an affiliation with The University of Newcastle.

The study was initiated by the growing interest in cooperative learning. I also had an interest in the development of the beginning writers in my classroom and sought to investigate how the implementation of the instructional strategy of cooperative learning could enhance the literacy learning of the students in my classroom. As part of my reflection into my literacy program for my Kindergarten / first class I decided to focus on the writing taking place within the classroom. The beginning writers study incorporated aspects of action research and was developed by initially planning a change to my practice, acting on and observing the process and any change consequences, reflecting again and replanning (Kemmis \& Wilkinson, cited in (Atweh, Kemmis, \& Weeks, 1998).

I decided to formulate questions about the ways in which I taught writing in my classroom and endeavoured to systematically investigate how I instigated, monitored 
and evaluated my writing sessions. My plan was to link the interest I had in cooperative learning, and its highlighted benefits over decades of research, with my interest in beginning writers. With an ongoing interest in cooperative learning I knew, that by taking an action research approach to my investigation, I could focus on a problem or question about the writing that was happening when I asked students to work together for certain writing tasks, act on this, observe any changes, reflect again and continue in this reflective process to improve the student writing outcomes.

I sought therefore to rigorously evaluate my current strategies and practices, plan for and implement some new ones and evaluate such actions, drawing conclusions on the basis of the findings (Macintyre, 1991 cited in Seider \& Lemma, 2004). The approach I took is also supported by Peters (2004) who stated: “Action Research, in particular, is depicted as a means of engaging practitioners in rigorous cycles of planning, observation, action and reflection, which can lead to change in understandings and practice" (Peters, 2004, p.536). These 'self-reflective spiral of cycles' as first mentioned by Lewin (1952) and supported by Elliott (1991) guide this type of practical action research with "analysis and reflection of the situation, rather than merely fact finding” (cited in Leitch \& Day, 2000, p.184).

This particular research approach also grew from a strong belief that teachers engaging in action research "grow personally and professionally and...this enables...them to influence other teachers toward improving curriculum and instruction" (Seider \& Lemma, 2004, p.221). As curriculum leader for English K-6 in a large city primary school in Newcastle, NSW Australia this was a strong personal mission. As a teacher researcher I wanted to be empowered, increasing my self confidence in decision making (Kincheloe, 1991 and Noffke, 1992 as cited in Morton, 2005) and as a result could help to empower other teachers towards improving student outcomes. As a result of such reflection in my action research approach my strong aim was to be more critical "moving beyond mere interpretation of situations to action resulting in a transformed educational setting" (Carr and Kemmis, 1986; Morton and Williams, 2002 cited in Morton, 2005, p.54).

The learning focus of this study was developed as a result of an interest in increasing the literacy skills in the early years of schooling, as well as an interest in the development of writing skills; the importance of developing regular classroom writing opportunities and the research into the value of collaborative learning in supporting higher achievement, thinking skills and deeper understanding (Hill \& Hill, 1990). It seems apparent that writing is crucial to school success and "is the primary means by which students demonstrate their knowledge in school and the major instrument that teachers use to evaluate academic performance" (Graham and Harris, in press, as cited in Saddler \& Graham, 2005, p.2). As well, many researchers have suggested that cooperative learning can promote academic achievement and social skills development (Johnson \& Johnson, 1987; Johnson \& Johnson, 1975; Johnson \& Johnson, 1994; Slavin, 1983; Slavin, 1987; Slavin, 1989; Stevens \& Slavin, 1995) and this belief led to the change in practice from mainly individual writing activities to paired experiences. It was my intention that this could then lead to larger group experiences if the outcomes of these paired experiences were successful and positive. 


\section{- Early writing development and collaboration - a selective review of related literature}

The development of strong literacy skills in the early years of schooling is an urgent priority of all Australian State and Federal governments (Department of Education and Science \& Committee, 1997) and has resulted in a number of studies: Mapping Literacy Achievement (Department of Education and Science \& Committee, 1997), 100 children turn 10 (Hill, Comber, Louden, Reid, \& Rivalland, 2002) as well as a recent (2004-2005) Australian National Inquiry Into the Teaching of Literacy (Department Education Science and Training, 2005). Literacy is defined in this most recent inquiry as not "just a set of cognitive abilities or skills based on an identifiable technology, for example alphabetic script on paper"... but needs to "be recognised as a social activity embedded within larger social practices and changing technologies" (Department Education Science and Training, 2005, p.4).

The 1991 Department of Employment Education and Training definition of literacy, which has been widely used in Australia in recent years, is used in the New South Wales Board of Studies English K-6 Syllabus (NSW Board of Studies, 1998):

"Literacy is the ability to read and use written information and to write appropriately in a range of contexts. It is used to develop knowledge and understanding, to achieve personal growth and to function effectively in our society. Literacy involves the integration of speaking, listening and critical thinking with reading and writing” (p.5).

This definition strongly advocates that the social nature of literacy is of utmost importance. Being literate enables people to function effectively in society. Teachers who recognise this and teach accordingly are preparing students for success in society.

\section{Literacy}

There are many factors that contribute to children's literacy development. Many teachers work with the belief that children do not fit neatly into developmental stages, and in terms of developing skills in literacy, each child has a unique way of making meaning (Clay, 1991). However the aspect I wanted to concentrate on in this study was the importance of social interaction in literacy development. Vygotsky's (1978) socio-cultural ideas of development assert that the adult, or expert, partners the child and scaffolds the present knowledge to new knowledge. This view would assert that children need social interaction for the scaffolding to take place. Vygotsky's work also indicated the link between children interacting socially with the development of higher order cognitive processes in writing (Vygotsky, 1978). Hill and Hancock support this notion that "Literacy is a social event: language is learnt in communities" (Hill \& Hancock, 1993, p.9). One technique used to enhance social learning in literacy situations is the use of cooperative/collaborative group work.

\section{Literacy and cooperative learning}

Cooperative learning research demonstrated that when students are organised into small heterogeneous teams (usually 2-6 students) and where academic tasks are 
solved with face to face interaction, individual accountability, positive interdependence and goal similarity (Hill \& Hancock, 1993; Hill \& Hill, 1990; Johnson \& Johnson, 1994; Slavin, 1995a) then academic abilities are improved. Johnson and Johnson's (1984) model also asserts that there should be some social skills instruction and debriefing (Johnson, 1984) so that as a result children's social skills are also improved.

Collaborative and cooperative talk can improve student outcomes. Tasks requiring cooperative talk encourage explanation as well as application of knowledge. Researchers (Hill \& Hill, 1990; Johnson \& Johnson, 1994; Slavin, 1995b) argue that there is a positive correlation between achievement and giving explanations. They also state that when knowledge is sought and constructed together, it is negotiated. Developing tasks with goal similarity, to ensure positive interdependence, therefore leads to a greater sense of personal responsibility. Hill and Hill (1990) further state that cooperative and collaborative learning supports higher achievement, develops thinking skills and deeper understanding, allows for more enjoyable learning, develops leadership skills, promotes positive views about others and self, helps self acceptance, builds self esteem, involves children and provides a sense of belonging (Hill \& Hill, 1990). The positive correlation between achievement and giving explanations, when knowledge is sought and constructed together and negotiated, supports the notion of the development of higher order cognitive processes in writing when children work together (Vygotsky, 1978). Children have different strengths and by working in collaboration each member of the group is able to develop higher achievements by sharing these different strengths.

In the study the term collaborative is used congruently with peer collaboration and this is defined as students offering equal amounts of help to each other. This "symmetric relationship" is based on one child explaining whilst completing a task but at the same time taking solutions, answers from the other member(s) of the team (De Haan \& Elbers, 2005). In comparison, peer tutoring is described as "one child in a teaching role, offering guidance and assistance to another child” (Morrow, 1993, p.13) and this definition is supported by De Haan and Elbers (2005, p.9) who describe the relationship as an "asymmetric" one. Peer tutoring can also occur under such cooperative conditions as utilised in the study. Therefore the study was developed with the understanding that "Where there is cooperative learning...the quality and quantity of support that each child receives in becoming a successful reader and writer is increased" (Hill \& Hancock, 1993, p.3).

\section{Writing and links to cooperative writing}

From earlier cited definitions about literacy it would seem that to improve writing skills children are required to write effectively for different purposes and different audiences in society and that students should be given plenty of opportunities to write regularly as, "students' regular classroom writing (which usually includes the processes of drafting, redrafting, and conferencing) reflects higher levels of writing ability than writing completed under more standardised conditions" (Department of Education and Science \& Committee, 1997, p.17). The Mapping Literacy Achievement Project (Department of Education and Science \& Committee, 1997) found that enjoyment of writing was paramount to writing success but that writing 
enjoyment declined from years 3 to 5 so there was thus an imperative for teachers to endeavour to foster enjoyment in writing from the beginning years of school.

Writing appears to be under represented in research and particularly in the early years. The most recent Australian National Inquiry into the teaching of literacy (2004-5) found that often writing is not given the emphasis that is needed and that too often reading instruction is the basis of most inquiries. Writing programs have developed over the years within Australia from approaches that encourage writing as production or encoding (1960's), to writing as creativity (1970's), to writing as process (1980's), to writing as genre (1990’s) (Harris, McKenzie, Fitzsimmons, \& Turbill, 2003). Many writing programs within Australia began to draw upon a social model of writing, based on Freebody and Luke's (1992, 1999, 2000) model of reading (Harris et al., 2003). The four sets of writing practices included in this social model are text encoder: written texts that can be read by others and conform to conventions and structures of written language; text participant: composing meaning; text user: writing for social purposes and text analyst: considering bigger picture consequences of what they write (Harris et al., 2003). .

By allowing children to work collaboratively, they think aloud and this enables them to think about their thought processes, and hence writing processes, more comprehensively than if they were working alone. When engaged, and with appropriate well matched scaffolding from the teacher, children are then able to collaborate on writing tasks ensuring they restate, clarify, justify, evaluate as well as reflect throughout the whole writing process (Bruner,1989, cited in McMahon, Raphael, Goatley, \& Pardo, 1997). Furthermore, when children share the writing they become more likely to take risks and become actively engaged with their writing as well as view errors as learning in progress (Cicalese, 2003).

In summary, it would appear that to become good writers, children should be given opportunities to interact regularly with enjoyable writing tasks, and by collaborating with others they are more able to scaffold each other's skills, knowledge and understandings to enable them to achieve higher order cognitive processes in writing. This project therefore was developed with the notion that collaborative writing should support students in their early writing attempts and in turn this should increase productivity as well as develop and support each other's writing skills.

\section{- Changing my writing program}

\section{What was happening before I intervened?}

My writing program prior to the study comprised of the students in my class writing individually. Tasks focussed on my students planning, reviewing and writing simple literary and factual texts for a variety of purposes, but they were asked to do this alone.

My writing program, before I decided to introduce collaborative approaches, had begun to draw upon the social model of writing (Harris et al., 2003). For the purpose of the study with my beginning writers I focussed mainly on the first three practices of the social model of writing advocated by Harris et al, 2003: text encoder, text participant, text user, that is, composing for meaning, conforming to the conventions 
and structures of written language and considering the social purpose of their writing (Harris et al., 2003). I also engaged my students to reach independent achievement by guiding them through a cycle of modelled, guided and independent writing (derived from the work of Macken, Martin, Kress, Kalantzis, Rothery \& Cope (1989), Mooney (1990) and Painter (1991 as cited in Harris et al., 2003). As students became independent I concentrated on collaborative approaches to writing.

\section{Assessing writing abilities}

Before the study, the level of the children's writing capabilities had been explored through careful observation. This was done during interactive, modelled and jointly constructed whole class writing sessions as well as in individual writing activities. After analysing writing samples, according to NSW Board of Studies (1998) outcomes and indicators, a variety of levels were identified. These were categorised into high, medium or low ability writers (or working towards, working at or working beyond expected stage levels).

It was at this stage that my program began to change as I sought to integrate my knowledge of the power of cooperative learning to improve student outcomes (Hill \& Hill, 1990; Johnson \& Johnson, 1994; Johnson, Johnson, \& Johnson Holubec, 1990; Slavin, 1995a) with how I felt students best learn to write. I had asked students to write alone at this phase and I felt that many of the group of writers I had were still working at an emergent writing stage and were only just beginning to show awareness of sounds in language. The beginning of my first phase of action research thus emerged when I organised these early writers into pairs with all writing times ensuring student interaction and opportunities to practise metacognitive skills (Van Keer \& Verhaeghe, 2005). I then began to formulate some questions:

What do children do when they write collaboratively (in pairs)?

What do both children offer to the writing process?

What do they talk about?

Are they on task more than when working individually?

What kinds of behaviours do they exhibit when working together?

What about the content of their writing?

What about the productivity levels when writing with different partnerships?

Will the type of partnership, that is the mix of ability levels, make a difference to these previous questions of behaviours, talk, content, productivity?

Could students at such an early stage of literacy achievement help each other write?

The main stages of the changes to my program were:

- developing collaborative skills in the students

- developing individual accountability procedures to ensure that each child was doing some of the writing.

- grouping students into pairs and after the first few sessions considering whether the topic should be given or self chosen and the differences to productivity with this difference

- grouping students into pairs and considering whether these should be same ability or mixed ability pairs,

- focussing on listening to and analysing the pre writing talk, 
- tape recording sessions in order to analyse the type of talk that was happening during the writing time and whether this talk assisted writing improvement?

- observing for evidence of peer collaboration, peer tutoring, co-writing and co-responding with consideration for their impact on the student's writing

\section{- Research design}

First phase intervention - developing collaboration amongst students

Prior to the writing focus of the study, I saw a need to actively teach basic interpersonal skills in order for collaboration between students to be useful (Johnson and Johnson, 1984). One way this was done was with the use of ' $Y$ ' charts (Hill and Hancock, 1993), which promote discussion of a particular social skill. For example when children are working in a think, pair, share activity another child is given the responsibility of looking for examples of good eye contact and other non verbal listening skill cues (eg nodding). At the end of the activity they then report back on whom they saw actively listening and how they 'saw' it. The 'y-chart' is then completed with a class brainstorm.

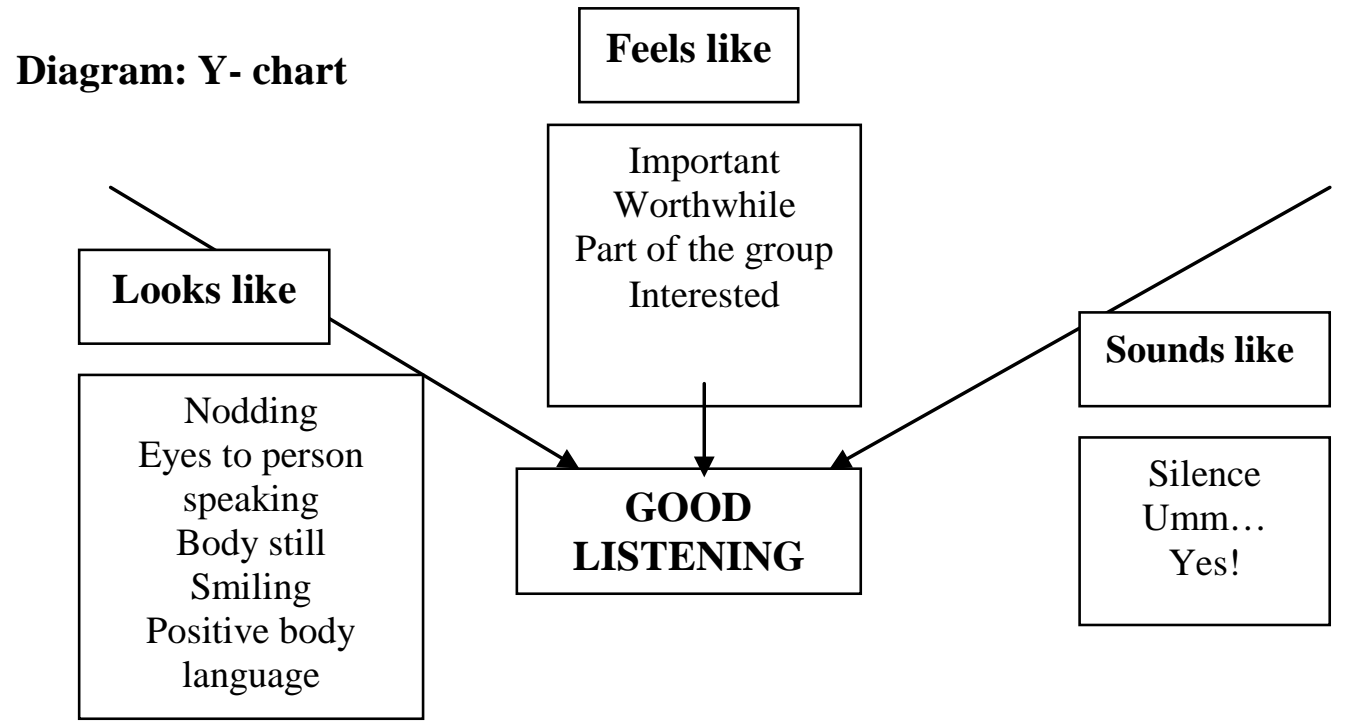

These Y-charts were comprehensively developed to practice such skills as turn taking and positive feedback, which were skills needed in order for students to write together in pairs. Small group games, that developed positive classroom ecology, were also employed in order to create a learning environment that fostered negotiated learning and cooperative skills.

After these whole class strategic teaching sessions students were organised into small heterogeneous teams (usually 2 students) with writing tasks solved with positive interdependence and goal similarity (Slavin 1995; Johnson and Johnson, 1994; Hill, 1993). By asking students to write in pairs, their knowledge was to be sought and constructed together and therefore was negotiated. The careful setting up of paired writing tasks, by for example ensuring there was some individual accountability, ensured that there was a level of personal responsibility.

Phase two - considerations of individual accountability 
At the beginning of the study, when analysing samples of writing and when conferencing with children, it was difficult to assess who had completed most of the writing task. Consequently a new aspect of the collaborative writing process was introduced. I asked each child to use a different coloured pencil. This, I hoped would help ensure individual accountability (positive interdependence)(Hill \& Hill, 1990; Johnson \& Johnson, 1975; Slavin, 1995a). Each child, through this technique, would become aware of the fact that it was possible to see if they were on task with the writing process and engaged with the learning and it would allow them also to self reflect on their individual efforts even though they were operating in a group situation.

\section{Phase three intervention - ability level consideration}

The collaborative writing experiences started by students being partnered in heterogeneous (mixed ability) partnerships. It was then decided to mix up the children and ask them to work at times with a teacher-allocated partner. At other times the children could choose their own partners. I wanted to determine whether the changing of high ability, middle ability or low ability writers had an impact on the level of co-writing, co-responding, student engagement and on task behaviours, as well as productivity (amount of words written). True cooperative learning experiences should involve heterogeneous groupings and this change to the study by ensuring that same ability partners worked alongside together at times, was an example of how researchers often adapt instructional innovations and models of cooperative learning to fit in with existing prior knowledge of teaching and experience (Cuban,1996, cited in Siegel, 2005).

\section{Phase four intervention - considering pre-writing talk}

Observing students writing and taking anecdotal notes had been a focus so far in the study. However I sometimes missed the pre-writing talk whilst setting the students off on their task, and it also appeared that when I was able to listen carefully at the beginning of a writing time, there was little occurring. They appeared to sit down and one partner would take charge of the task and start it without talking about it first. This led me to intervene and start tape recording one pair's talk during each writing session in order to more easily analyse the type of talk that was happening during the writing time. I hope that this would help me to hear whether this talk indicated on or off task behaviours and whether this talk assisted writing improvement.

Phase five intervention - from further reading - recognition and noting of peer collaboration and peer tutoring, co-writing and co-responding

Looking further at the writing process led me to read more about the area of writing in collaboration. I discovered research about peer collaboration and peer tutoring and my analysis of the transcripts of recorded talk started to determine that at times I could see aspects of both happening. I also then began to look for evidence of cowriting and co-responding. During the analysis of the transcripts I could observe the level of co-writing and co-responding that occurred during different writing approaches (Saunders, 1989, cited in McCarthey \& McMahon, 1992). It started to become apparent that some students collaborated on every task including forming of ideas, sentence forming and spelling of individual words within the sentence whereas 
others appeared to 'co-responding' and only really interact the revising (editing) process, that is when a sentence had been written by one student another may offer advice about a word that was missed, or misspelt. Saunders' (1989) definition of 'helping,' when writers voluntarily help during the writing process (cited in McCarthey et al, 1992) is important when students wrote with others. It was also apparent that students should have the feeling of trustworthiness of their partners when they sought help (Nelson Le-Gall, 1992). If they know they will not be criticised for seeking help, and if the help given is seen as effective, they may seek help again.

\section{Triangulation}

The case study used multiple data collection strategies or triangulation (Stringer, 2004) to increase reliability and validity. During the six month study, persistent, participant and intensive observation (Stringer, 2004) was used. This improves the internal validity of a study as different methods of data collection allowed for comparison of information and assessed the sufficiency of the data. Many strategies were used to collect evidence. These involved observation, anecdotal note keeping and reflections in a journal; conferencing with the children as they wrote also ensured the validity of the action research process, establishing credibility and dependability and recording interactions. At the start of the study it was difficult to anticipate how difficult it would be to really listen to the interactions of a pair without being disturbed by assistance being sought from others, or general classroom noise. This is why the tape recorded sessions were introduced part way through. Verbal interactions were transcribed from the tape recordings. Finally the samples of work were collected and analysed.

\section{- What I learnt about children collaborating in writing}

\section{Individual accountability}

Dominance of partnerships began to be examined at the beginning of the study. Earlier observed sessions showed the domination of one partner but after introducing the coloured pencils, it ensured both students accountability, with positive interdependence being made clear and students being made to “...feel a sense of personal responsibility to do their fair share of the work (Johnson and Johnson, 1992, p.193). It was obvious, after the introduction of the coloured pencils, how the task was shared. Students shared tasks in different ways. These included sharing the writing one letter at a time (Ross and Aaron - appendix 1), one word at a time (Cassie and Casey- appendix 2) or two words, or a mixture of turn taking, at a time (Hayley and Victoria- appendix 3). The use of different coloured pencils was still used after the study finished as it was a way of students realising that visually I was aware of their contribution.

\section{Pre-writing talk}

Analysis of the first few observations suggested an absence of pre-writing talk. The dominant personality or higher ability writer tended to instigate the start of the writing process by either writing a title and / or the lines (which represent the words to be written in that sentence.) 
There was also no pre-writing talk at any of the seven tape recorded sessions. The introduction of the tape recorder was to try and improve my ability to really listen to the interactions of a pair, without being disturbed by assistance being sought from others, and to alleviate problems of general classroom noise. However as the study progressed it became obvious that even when not being closely observed with me sitting on the same table as the students, they were still not involved in pre-writing talk. Maybe the tape recorder restricted this as they felt that they were being "watched" and should therefore start to write immediately. Perhaps the students felt there was the pressure of individual accountability and I would be checking that they had started their task immediately as it was being taped. The absence of pre-writing talk suggests that whoever has the next turn to write decides on how the writing will continue. I reminded children to talk and think before writing after noticing this absence of planning prior to writing. However this did not appear to happen at subsequent sessions. It was disappointing that collaborative learning did not improve pre-writing skills.

\section{Re-reading for meaning}

The use of the tape recorder also highlighted another skill that beginning writers use constantly. Observations and transcription of tape recorded sessions revealed that students used the re-reading strategy constantly to determine meaning of their written texts. This strategy is possibly relied on more when students wrote collaboratively in pairs than during individual writing sessions, as the two students had to determine the sense of the partner's writing before continuing on. Although the communication suggests a slowing down of the writing process, a suggestion that this could decrease productivity, the results conclude that productivity increased dramatically over the course of the study with the average number of words increasing from almost eight in April to twenty-one in September.

\section{Cooperative behaviours / skills analysis}

As the study continued I was able to analyse, again mainly through the use of transcribed tape recorded sessions, some cooperative behaviours. Turn taking was the most common cooperative skill used in the study and this skill was developed from the beginning to end. Due to the individual accountability built into the task, individuals were more likely to encourage each other's efforts to achieve (Johnson et al, 1994). Some of the statements made by the children support this notion of turn taking and peer tutoring or peer collaboration.

“We'll write about yours Ross!" (his news)

"How about we make it Marvella and the star?" (suggest alternative, creative story line / title)

"You write dress - make a space there!" (help with writing conventions)

"Come on we have to think of some more ideas!" (the joint goal acknowledged)

"Do you know how to spell 'our'?" (child sought assistance and acknowledged partner's strength)

Ability level of child and its impact on the study 
I found that the numbers of words increased if they were given a partner (by me or through random allocation) rather than self selecting one.

\begin{tabular}{|l|l|}
\hline First phase (7 sessions) & Mean (average no. of words written) \\
\hline Given partner & $\mathbf{1 1 . 2 8}$ \\
\hline Own partner & 9.6 \\
\hline Second phase (7 sessions) & \\
\hline Given partner & $\mathbf{2 0 . 5 5}$ \\
\hline Own partner & 13.95 \\
\hline
\end{tabular}

When self selecting a partner most students chose different students each time and so developing a writing relationship was difficult. On the other hand Casey and Tayler selected each other three times during the study. They were both high ability writers and often felt frustrated in the peer teaching role. They enjoyed the fluency of writing with each other.

\section{Peer tutoring}

The strategy of constantly re-reading in order to ensure the writing made sense needed to be constantly encouraged and modelled during shared / modelled writing sessions with these beginning writers. The strategy of re-reading for sense making, worked well with beginning writing demonstrations. When two high ability children worked together there was an absence of talk or interaction. This could be because their knowledge of high frequency words was good, that they recorded these silently and could also because their more advanced reading skills enabled them to reread quickly and silently. In session 14 a child was taught this re-reading strategy by another and then went on to use it in a different partnership (session 15).

\section{See figure 1.}

Daniel "We."

Mitchell "e, we, e, e."

Daniel "No! 'w', 'e'."

Daniel rereading "On Wednesday we....went!"

Mitchell "This one?" (pointing at alphabet card?)

Daniel "We nt 't' 'nt'." sounding out.
Daniel starts the interaction but it is obviously Mitchell's turn to write the letters.

Mitchell attempts to sound it out and Daniel gets annoyed that he doesn't know how to write it.

Daniel is using the strategy that Tayler has demonstrated last week - rereading to find out what word should be written next! Peer teaching has worked!! Mitchell seeking help / clarification. Daniel sounding out unknown words.

Various observations supported the notion of children working in collaboration and using their own strengths, with the "zone of proximal development" shifting depending on what was being discussed or attempted. In session 14 a child shares his knowledge of the length of words.

See figure 2 . 
Together "N', 'i', 'i', 'n', 'n'" Sounding out together.

Tayler "I think I know how to spell that!"

Daniel "plna"

Tayler "Make your line bigger!"

Together "t', 's'."

Tayler Rereading

Daniel "I know how to spell 'we'".

Tayler "Hang on, it might not be 'we'."

They continued writing and then preceded to argue about what comes next. Rereading and pointing at words to justify.

Tayler is excited when he knows how to spell a word.

Tayler obviously knows the word Daniel is attempting is a longer one than Daniel has drawn the line for.

Helping each other.

Tayler uses this strategy to work out the next word he is to write.

Daniel excited about knowing how to spell a word.

Tayler wants Daniel to be sure this is the right word to write next - maybe he is encouraging him to use the previous strategy?

Arguing about ideas / meaning?

Another child in a session remembers a teaching tip about not using too many "ands" and she reminds her partner.

\section{See figure 3.}

Hayley kept on task and Victoria went on and off task.

Hayley kept repeating "I'll tell the teacher.."

\section{Hayley tried to continue but found it hard to} re-read Victoria's writing attempts. "What does this say?"

Victoria "Remember, Miss Ferguson said to not write too many 'ands'."

\section{Hayley didn't comment and didn't alter writing (maybe did not understand?).}

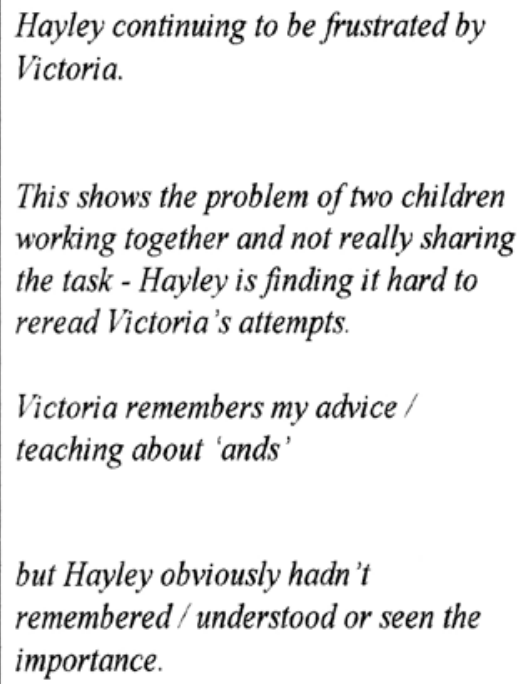
Victoria.

This shows the problem of two children working together and not really sharing the task - Hayley is finding it hard to reread Victoria's attempts.

Victoria remembers my advice / teaching about 'ands'

but Hayley obviously hadn't remembered/understood or seen the importance.

Two other students help each other with spellings and reinforce the alphabet by singing it together. 


\section{See Figure 4.}

\section{August}

Ross and Aaron

Information Report - "All we know about Space"

Aaron Ross taking it in turns to write lines to represent words, but not conferring before they do this. No pre writing planning occurring.

Ross said the word they were attempting to write and Aaron saying the sound(s) he could hear. Ross said the letter name and wrote it.

Ross "This is how you write an 'I', 'p'!

Aaron "'p' for Peter!" (saying the alphabet aloud and looking at the alphabet card for the ' $p$ '.)

Ross "O"

Aaron "I'll draw the 'o'". (Re-reading and heard $a^{\prime}$ 't' that Ross had obviously previously missed.)

"How do. you draw a 'b'?"

Ross "Easy!" (Showing Aaron the alphabet card and singing the alphabet to get to the letter).

"We're helping each other, aren't we?"
This is a very common occurrence to have no pre-writing talk and planning.

Sharing the load and their knowledge of different letter / sound correspondences. "Zone of proximal development' shifting continuously.

Peer teaching

Using the alphabet card to find out how to write letters.

Aaron wants to write the letters he knows how to write - 'o' is in his name Rereading is a strategy they don 't use enough.

Ross also using the alphabet card to locate a letter for Aaron.

Co-operative behaviour,

acknowledging that they both have

knowledge to share

These transcripts thus highlight peer tutoring as a powerful collaborative teaching strategy. When engaged, and with appropriate well matched scaffolding from the teacher, children are able to collaborate on writing tasks by ensuring they restate, clarify, justify, evaluate as well as reflect throughout the whole writing process (Bruner,1989, cited in McMahon et al., 1997).

\section{Peer collaboration}

There were two instances noted from the tape recorded sessions where I could claim interactions of peer collaboration. Casey and Cassie gave each other equal help in one session "How about I do the letters and then you do the letters?" and Ross and Matthew in another "I learnt to write ' $o$ ' and 't'!". "That's an ' $h$ ', this is an ' $n$ '”. Interestingly both pairs of students were similar ability whereas clear examples of peer tutoring (locating letters, telling what letters represented different sounds, sounding out for spelling, re-reading work) resulted when students were paired with a different ability partner. By allowing children to work collaboratively, they think aloud and this enables them to think about their thought processes, and hence writing processes, more comprehensively than if they were working alone.

I began to note that at times the higher ability partner became frustrated and hindered in this peer tutoring role so it was important for these students to be given opportunities to not always work in such partnerships. I began to recognise that they needed opportunities at times to work beyond their own individual capabilities by 
working with others of the same ability level as well as other times when they could be in this peer teaching role.

'Helping' occurred numerous times in the study, when students peer tutored and peer collaborated with letter names, sounds, locating letters on an alphabet strip, showing where spaces need to go between words, trying to get partner back on task, reminding partner about turn taking, encouraging re reading for meaning and demonstrating one to one correspondence. These helping behaviours were more apparent when listening to and transcribing the tape recorded sessions. This suggests that as teachers focussed observations are very necessary in order to examine and understand what is occurring in the classroom.

Some students were identified by their peers when interviewed at the end of the study, as 'good helpers' and interestingly more girls than boys were identified. Good helpers were perceived as caring and cooperative members of the class, both being supporting and accepting. The study suggests that 'good helping' skills need to be made explicit, that is the question needs to be constantly explored with the students: What does it mean to be caring and cooperative?

I had a strong belief that collaborative learning supports higher achievement, develops thinking skills and deeper understanding, allows for more enjoyable learning, develops leadership skills, promotes positive views about others and self, helps self acceptance, and builds self esteem whether this be with a similar ability or mixed ability partner. As a result it was a realisation that I would continue to change these partnerships in my writing program and at times have students write with an opportunity to be a helper and provide scaffolding of others' learning and other times give higher ability students an opportunity to bounce ideas, develop thinking skills and enjoy learning with a similar ability partner. As well as the value of students assisting in skills development, the "helping" aspect of providing social support in a learning task was also obviously of assistance when encouraging quantity of writing.

This increased productivity (quantity) is shown in the table (see appendix 4) which shows an increase in productivity over the fourteen sessions of collaborative writing. H,M,L (High, middle, low) refers to the ability of the partner. Collaborative writing sessions were approximately 20-45 minutes. This increased quantity may not have been as a direct result of the study and of the placing of students in pairs to write however it depended significantly on the partner they were working with. Lower ability students reduce fluency due to their inability to write high frequency words quickly, but also higher ability students tended to strive for perfection, both factors slowing down the amount written. Tayler (High ability) worked with four lower ability, three middle ability and three higher ability partners during the study. He demonstrated in a number of sessions that he not want to progress to writing the next word until he was sure the previous one was worked out correctly. This slowed down the process of writing for both him and his partner. Hayley (Middle ability) however was a great risk taker and this speeded up the process of her writing, increasing productivity.

\section{Implications for my teaching}


The study has supported the findings of others who have researched collaboration and literacy. These studies show how children share strengths (Vygotsky, 1978) as well as the positive outcomes of students working together (Johnson \& Johnson, 1987; Johnson \& Johnson, 1975; Johnson \& Johnson, 1994; Slavin, 1983; Slavin, 1987; Slavin, 1989; Stevens \& Slavin, 1995).

My action research approach has enabled me to closely observe, analyse, change, reflect and re-plan my writing program allowing me to make teaching decisions based on action research. The study found various types of interaction and involvement depending on a number of variables. Mixed ability grouping results suggest that teachers should vary their partnerships. When children work with a higher ability partner, peer tutoring is likely to occur in various ways. Although most enjoy the tutoring role, some students get frustrated. This suggests teachers should vary their partnerships and allow students at times to work with similar abilities in order to share strengths and jointly help (peer collaborate). At times "issues relating to peer acceptance and reading competence" can "complicate children's interactions during literacy events” (Matthews \& Kesner, 2003, p.208).

Children shared the writing tasks in different ways, but after the different coloured pencils were introduced to encourage individual accountability (Johnson \& Johnson, 1994) the children were most likely to write a word in turn and this then improved both children's writing production. This individual accountability is of crucial importance when working with cooperative activities and the careful division of the task in order to achieve task interdependence as well as resources to achieve resource interdependence are two of the crucial elements suggested by Johnson and Johnson (1994). It is this cooperative incentive structure that is distinctive to cooperative learning (Killen, 2003). A the start of the study I had not really considered these crucial elements and therefore the sharing of the tasks was sometimes not apparent with the higher ability student taking over the majority or all of the writing.

Some of the cooperative behaviours displayed included turn taking, helping and supporting. Social skills development is also crucial to cooperative activities and the study highlighted the need to be constantly explicit about 'good helping' skills.

Productivity was also examined and the study found a positive correlation between being given a topic to write about with explicit teaching input and scaffolding, as well as when children were given a partner to write with, rather than self selecting their own partner. Off task behaviours were more common when working with a friend. Peer collaboration occurred between similar ability partners and this was a common choice for children to make.

These conclusions explain the some of the benefits of children writing together. This small sample of students benefited from working in collaboration with others and enhanced my understanding about children's collaborative writing processes and behaviours by my continual reassessing of my teaching process. The study certainly demonstrated the complexity involved in collaborative writing sessions and demonstrated how teachers can learn from listening to their students' conversations. It helped to impact on my professional practice by enabling informed choices about teaching/learning in the context of literacy and collaboration. 
Somekh (2003) cites Elliott (1994) who has stated 'Through action research the ideas of theorists are problematised'. She goes on to say:

"By this I think he means that through action research all practitioners, across professions and sectors, problematise their own and other people's theories as an integral part of their day-to-day experience. Other people's theories become personally owned, as we engage with them experientially, once action research becomes a way of life” (Somekh, 2003, p.260).

My intention is to further 'problematise' my own and other's theories on collaborative and cooperative learning and engage with them experientially with other teachers as action research becomes a way of life in their classrooms.

Anderson, G. L., Herr, K., \& Nihlen, A. S. (1994). Studying your own school: An educator's guide to qualitative practitioner research. Thousand Oaks, CA: Corwin.

Atweh, B., Kemmis, S., \& Weeks, P. (Eds.). (1998). Action Research in Practice; partnership for social justice. NY: Routledge.

Cicalese, C. (2003). Children's perspectives on interactive writing versus independent writing in primary grades. Unpublished MA, Kean University, New Jersey.

Clay, M. (1991). Becoming literate : the construction of inner control. Portsmouth, N.H: Heinemann.

De Haan, M., \& Elbers, E. (2005). Peer tutoring in a multiethnic classroom in the Netherlands: a multiperspective analysis of diversity. Comparative Education Review, 49(3), 365-388.

Department Education Science and Training. (2005). National Inquiry Into the Teaching of Literacy.

Department of Education and Science, \& Committee, N. S. E. L. S. M. (1997). Mapping Literacy Achievement: Results of the 1996 National School English Literacy Survey. Camberwell, Vic.: Dept. of Employment, Education, Training and Youth Affairs.

Dewey, J. (1933). How we think : a restatement of the relation of reflective thinking to the educative process. Boston: D.C. Heath.

Grushka, K., Hinde McLeod, J., \& Reynolds, R. (2005). Reflective thinking. Reflective Practice, 6, No.5(May), 239-246.

Harris, P., McKenzie, B., Fitzsimmons, P., \& Turbill, J. (2003). Writing in the Primary School Years. Tuggerah, NSW: Social Science Press.

Hill, S., Comber, B., Louden, W., Reid, J., \& Rivalland, J. (2002). 100 children turn 10: A longitudinal study of literacy development from the year prior to school to the first four years of school, a two volume report. Canberra: Department for Education, Science and Training.

Hill, S., \& Hancock, J. (1993). Reading and Writing Communities: Cooperative Literacy Learning in the Classroom. Armadale: Eleanor Curtain.

Hill, S., \& Hill, T. (1990). The Collaborative Classroom: a guide to cooperative learning. South Yarra: Eleanor Curtain.

Johnson, D. (1984). Circles of learning : cooperation in the classroom. Alexandria, VA: Association for Supervision and Curriculum Development.

Johnson, D., \& Johnson, F. (1987). Joining together: group theory and group skills. Englewood Cliffs, NJ: Prentice-Hall. 
Johnson, D., \& Johnson, R. (1975). Learning together and alone : cooperation, competition, and individualization. Englewood Cliffs, NJ: Prentice-Hall.

Johnson, D., \& Johnson, R. (1994). Learning Together and Alone: Cooperative, competitive and individualistic learning. Boston, MA: Allyn and Bacon.

Johnson, D., Johnson, R., \& Johnson Holubec, E. (1990). Circles of learning : cooperation in the classroom. Alexandria, Va: Association for Supervision and Curriculum Development.

Killen, R. (2003). Effective teaching strategies: lessons from research and practice (Third ed.). Tuggerah, NSW: Social Science Press.

Leitch, R., \& Day, C. (2000). Action research and reflective practice: towards a holistic view. Educational Action Research, 8(1), 179-193.

Matthews, M., \& Kesner, J. (2003). Children learning with peers: The confluence of peer status and literacy competence within small-group literacy events. Reading Research Quarterly, 38(2), 208.

McCarthey, S., \& McMahon, S. (1992). Peer interaction during writing. In R. Lazarowitz \& N. Miller (Eds.), Interaction in cooperative groups: the theoretical anatomy of group learning: Cambridge University Press.

McMahon, S., Raphael, T., Goatley, V., \& Pardo, L. (Eds.). (1997). The Book Club Connection: literacy learning and classroom talk. NY: International Reading Association.

Mills, G. E. (2003). Action research: A guide for the teacher researcher (2nd ed.). Columbas, Ohio: Merrill Prentice Hall.

Morrow, L. (1993). Promoting independent reading and writing through self-directed literacy activities in a collaborative setting. Athens: National Reading Research Center.

Morton, M. L. (2005). Practicing praxis: mentoring teachers in a low income school through collaborative action research and transformative pedagogy. Mentoring and Tutoring, 13(1), 53-72.

Nelson Le-Gall, S. (1992). Childrens instrumental help-seeking: it's role in the social acquisition and construction of knowledge. In R. Lazarowitz \& N. Miller (Eds.), Interaction in cooperative groups: the theoretical anatomy of group learning: . Cambridge: University press.

NSW Board of Studies. (1998). English K-6 Syllabus. Sydney: Board of Studies.

NSW Department of Education and Training. (2003). Quality teaching in NSW public schools : an annotated bibliography. Sydney: Professional Support and Curriculum Directorate.

Peters, J. (2004). Teachers engaging in action research: challenging some assumptions. Educational Action Reseach, 12(4), 535-555.

Rowe, K. J., \& Rowe, K. S. (2002). What matters most: Evidence-based findings of the key factors affecting the educational experiences and outcomes for girls and boys throughout their primary and secondary schooling: ACER, Melbourne.

Saddler, B., \& Graham, S. (2005). The effects of peer-assisted sentence combining instruction on the writing performance of more and less skilled young writers. Journal of educational Psychology, 97(1), 43-54.

Schon, D. (1983). The reflective practitioner : how professionals think in action. New York: Basic books.

Seider, S., \& Lemma, P. (2004). Perceived effects of action research on teachers' professional efficacy, inquiry mindsets and the support they received while 
conduction projects to intervene into student learning. Educational Action Research, 12(2), 219-238.

Siegel, C. (2005). Implementing a research based model of cooperative learning. Journal of Educational Research, 98(6), 339-351.

Slavin, R. E. (1983). Effects of Cooperative Learning on the Social Acceptance of Mainstreamed Academically Handicapped Students. Journal of Special Education, 7(2), 171-182.

Slavin, R. E. (1987). Cooperative Learning and the Cooperative School. Educational Leadership, 45(3), 7-13.

Slavin, R. E. (1989). School and classroom organization. Hillsdale, NJ: Erlbaum Associates.

Slavin, R. E. (1995a). The Cooperative Elementary School: Effects on Students' Achievement, Attitudes, and Social Relations. American Educational Research Journal, 32(1), 321-351.

Slavin, R. E. (1995b). Cooperative learning : theory, research, and practice (Vol. 2nd Edition). Boston: Allyn and Bacon.

Somekh, B. (2003). Theory and Passion in Action Research. Educational Action Research, 11(247-264).

Stevens, R., \& Slavin, R. E. (1995). Effects of a Cooperative Learning Approach in Reading and Writing on Academically Handicapped and Non-handicapped Students. The Elementary School Journal, 95(3), 241-263.

Stringer, E. (2004). Action Research in Education. NJ: Pearson Education.

Van Keer, H., \& Verhaeghe, J. (2005). Effects of explicit reading strategies instruction and peer tutoring on second and fifth graders' reading comprehension and self-efficacy perceptions. Journal of Experimental Education, 73(4), 291-329.

Vygotsky, L. S. (1978). Mind in Society: the development of higher psychological processes. Cambridge: Harvard University Press. 
Appendix one

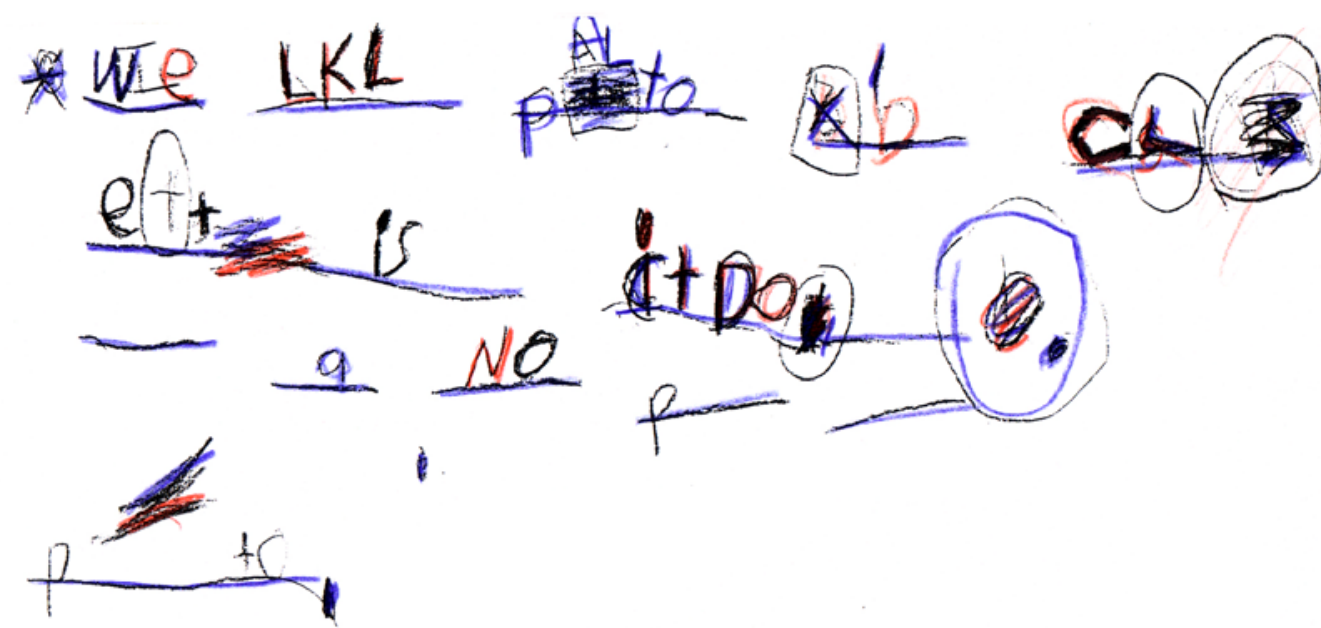

(12)

Appendix two Casey-Green Cassie-Blue
$*$

MODN MORW WVas

SaD She $\frac{\text { waNted }}{\text { E the }}$

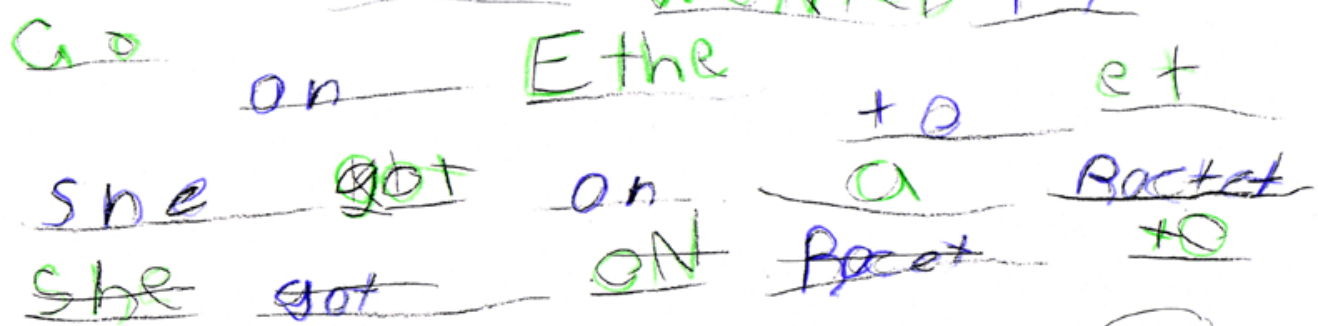

ge .... to Ethe...

32

Appendix 3

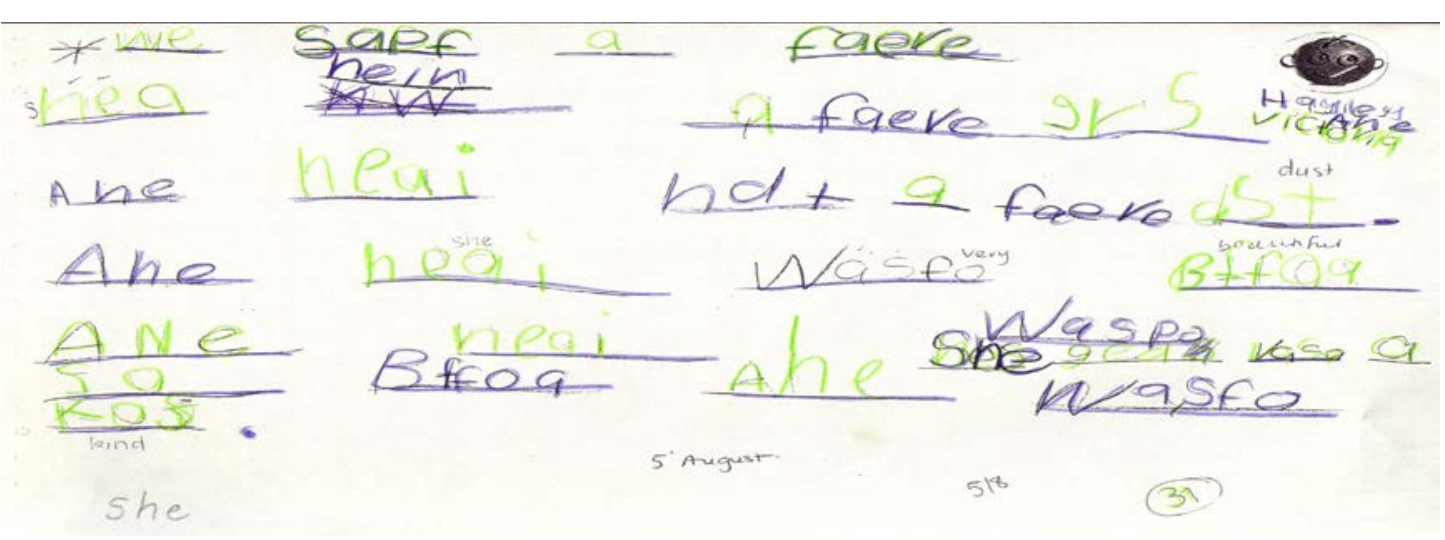

19 


\section{Appendix 4}

\begin{tabular}{|c|c|c|c|c|c|c|c|c|c|c|c|c|c|c|}
\hline \multicolumn{15}{|c|}{ Date/number of words written } \\
\hline Name: & $24 / 4$ & $29 / 4$ & $6 / 5$ & $22 / 5$ & $\underline{17 / 6}$ & $\underline{24 / 6}$ & $15 / 7$ & $\underline{22 / 7}$ & $29 / 7$ & $\underline{5 / 8}$ & $12 / 8$ & $19 / 8$ & $2 / 9$ & $24 / 9$ \\
\hline $\begin{array}{l}\text { Hayley } \\
\text { (High } \\
\text { ability) }\end{array}$ & $\begin{array}{c}9 \\
M\end{array}$ & $\begin{array}{c}12 \\
\mathrm{~L}\end{array}$ & $\begin{array}{l}15 \\
\mathrm{H}\end{array}$ & $\begin{array}{l}11 \\
\mathrm{~L}\end{array}$ & $\begin{array}{c}12 \\
\mathrm{~L}\end{array}$ & $\begin{array}{c}13 \\
\mathrm{M} / \\
\mathrm{H}\end{array}$ & $\begin{array}{l}17 \\
M\end{array}$ & abs & $\begin{array}{l}24 \\
M\end{array}$ & $\begin{array}{l}31 \\
M\end{array}$ & $\begin{array}{l}19 \\
M\end{array}$ & $\begin{array}{l}17 \\
M\end{array}$ & $\begin{array}{l}45 \\
M\end{array}$ & $\begin{array}{l}19 \\
M\end{array}$ \\
\hline Jami (M) & $\begin{array}{l}10 \\
\mathrm{M}\end{array}$ & $\begin{array}{l}6 \\
M \\
\end{array}$ & $\begin{array}{l}6 \\
\mathrm{~L} \\
\end{array}$ & $\begin{array}{l}17 \\
\mathrm{M}\end{array}$ & $\begin{array}{l}16 \\
M\end{array}$ & $\begin{array}{l}13 \\
\mathrm{M}\end{array}$ & $\begin{array}{l}11 \\
\mathrm{M}\end{array}$ & $\begin{array}{l}12 \\
\mathrm{M}\end{array}$ & $\begin{array}{c}13 \\
\mathrm{~L}\end{array}$ & $\begin{array}{l}19 \\
\mathrm{M}\end{array}$ & $\begin{array}{c}22 \\
\mathrm{H} \\
\end{array}$ & $\begin{array}{c}13 \\
\mathrm{H} \\
\end{array}$ & $\begin{array}{l}8 \\
M\end{array}$ & $\begin{array}{l}55 \\
\mathrm{H}\end{array}$ \\
\hline $\begin{array}{l}\text { Victoria } \\
\text { (M) }\end{array}$ & $\begin{array}{l}10 \\
M\end{array}$ & $\begin{array}{l}7 \\
\mathrm{~L}\end{array}$ & abs & $\begin{array}{l}15 \\
M\end{array}$ & $\begin{array}{l}5 \\
M\end{array}$ & abs & $\begin{array}{l}9 \\
M\end{array}$ & $\begin{array}{l}5 \\
L\end{array}$ & $\begin{array}{l}12 \\
M\end{array}$ & $\begin{array}{l}31 \\
M\end{array}$ & abs & $\begin{array}{l}17 \\
M\end{array}$ & $\begin{array}{l}23 \\
M\end{array}$ & $\begin{array}{l}22 \\
M\end{array}$ \\
\hline $\begin{array}{c}\text { Cassie } \\
\text { (M) }\end{array}$ & $\begin{array}{l}5 \\
L\end{array}$ & $\begin{array}{c}7 \\
M / L\end{array}$ & $\begin{array}{r}10 \\
M / L\end{array}$ & $15 \mathrm{M}$ & $\begin{array}{l}5 \\
M\end{array}$ & $\begin{array}{l}13 \\
\mathrm{M} / \\
\mathrm{M}\end{array}$ & $\begin{array}{c}16 \\
\mathrm{~L}\end{array}$ & $\begin{array}{l}6 \\
M\end{array}$ & $\begin{array}{c}32 \\
\mathrm{~L}\end{array}$ & abs & $\begin{array}{c}16 \\
\mathrm{~L}\end{array}$ & $\begin{array}{c}13 \\
\mathrm{~L}\end{array}$ & $\begin{array}{c}18 \\
\mathrm{~L}\end{array}$ & $\begin{array}{c}41 \\
\mathrm{~L}\end{array}$ \\
\hline $\begin{array}{c}\text { Casey } \\
\text { (H) }\end{array}$ & $\begin{array}{l}8 \\
M\end{array}$ & $\begin{array}{l}19 \\
\mathrm{H}\end{array}$ & $\begin{array}{l}10 \\
M\end{array}$ & $\begin{array}{l}33 \\
M\end{array}$ & $\begin{array}{l}10 \\
M\end{array}$ & $\begin{array}{l}11 \\
M\end{array}$ & $\begin{array}{l}8 \\
\mathrm{H}\end{array}$ & $\begin{array}{l}10 \\
\mathrm{H}\end{array}$ & $\begin{array}{c}32 \\
\mathrm{H}\end{array}$ & abs & $\begin{array}{l}22 \\
M\end{array}$ & $\begin{array}{l}19 \\
M\end{array}$ & $\begin{array}{l}45 \\
M\end{array}$ & $\begin{array}{l}44 \\
M\end{array}$ \\
\hline $\begin{array}{c}\text { Larrissa } \\
\text { (M) }\end{array}$ & $\begin{array}{l}8 \\
\mathrm{H}\end{array}$ & $\begin{array}{l}8 \\
M\end{array}$ & $\begin{array}{l}10 \\
\mathrm{H}\end{array}$ & abs & $\begin{array}{l}5 \\
\mathrm{H}\end{array}$ & $\begin{array}{l}10 \\
M\end{array}$ & $\begin{array}{l}6 \\
\mathrm{~L}\end{array}$ & $\begin{array}{l}12 \\
M\end{array}$ & $\begin{array}{c}21 \\
\mathrm{M} / \mathrm{H}\end{array}$ & abs & $\begin{array}{l}8 \\
M\end{array}$ & $\begin{array}{c}19 \\
\mathrm{H}\end{array}$ & $\begin{array}{l}23 \\
M\end{array}$ & $\begin{array}{l}31 \\
M\end{array}$ \\
\hline $\begin{array}{c}\text { Daniel } \\
(\mathrm{M})\end{array}$ & $\begin{array}{c}4 \\
M\end{array}$ & $\begin{array}{l}6 \\
M \\
\end{array}$ & $\begin{array}{c}7 \\
\mathrm{M} / \mathrm{L} \\
\end{array}$ & abs & $\begin{array}{l}10 \\
\mathrm{H}\end{array}$ & $\begin{array}{l}10 \\
M\end{array}$ & $\begin{array}{l}11 \\
M\end{array}$ & $\begin{array}{l}7 \\
M \\
\end{array}$ & $\begin{array}{c}21 \\
\mathrm{M} / \mathrm{H} \\
\end{array}$ & abs & $\begin{array}{l}19 \\
\mathrm{M}\end{array}$ & $\begin{array}{c}23 \\
\mathrm{H} \\
\end{array}$ & $\begin{array}{c}15 \\
\mathrm{~L}\end{array}$ & $\begin{array}{l}22 \\
M\end{array}$ \\
\hline $\begin{array}{c}\text { Tayler } \\
\text { (H) }\end{array}$ & $10 \mathrm{~L}$ & $\begin{array}{c}19 \\
\mathrm{H}\end{array}$ & $\begin{array}{l}15 \\
M\end{array}$ & abs & $\begin{array}{c}11 \\
L\end{array}$ & abs & $\begin{array}{l}8 \\
\mathrm{H}\end{array}$ & $\begin{array}{c}10 \\
\mathrm{H}\end{array}$ & $\begin{array}{c}21 \\
\mathrm{M} / \mathrm{M}\end{array}$ & $\begin{array}{l}8 \\
\mathrm{~L}\end{array}$ & $\begin{array}{c}16 \\
\mathrm{H}\end{array}$ & $\begin{array}{l}23 \\
M\end{array}$ & abs & $\begin{array}{c}28 \\
\mathrm{~L}\end{array}$ \\
\hline $\begin{array}{l}\begin{array}{c}\text { Mitchell } \\
\text { (L) }\end{array} \\
\end{array}$ & $\begin{array}{l}10 \\
\mathrm{H}\end{array}$ & $\begin{array}{l}7 \\
M \\
\end{array}$ & $\begin{array}{c}6 \\
M \\
\end{array}$ & $\begin{array}{l}11 \\
\mathrm{M}\end{array}$ & $\begin{array}{l}12 \\
M\end{array}$ & $\begin{array}{c}7 \\
\text { L/M } \\
\end{array}$ & $\begin{array}{c}16 \\
\mathrm{H}\end{array}$ & abs & abs & $\begin{array}{l}8 \\
M \\
\end{array}$ & abs & $\begin{array}{l}5 \\
\mathrm{~L}\end{array}$ & $\begin{array}{l}15 \\
\mathrm{M}\end{array}$ & $\begin{array}{l}19 \\
\mathrm{M}\end{array}$ \\
\hline $\begin{array}{l}\text { Aaron } \\
\text { (L) }\end{array}$ & $\begin{array}{l}5 \\
\mathrm{H}\end{array}$ & $\begin{array}{l}12 \\
M\end{array}$ & abs & abs & $\begin{array}{c}11 \\
\mathrm{H}\end{array}$ & $\begin{array}{c}7 \\
\text { L/M }\end{array}$ & $\begin{array}{l}6 \\
M\end{array}$ & $\begin{array}{l}5 \\
M\end{array}$ & $\begin{array}{l}13 \\
M\end{array}$ & $\begin{array}{l}8 \\
\mathrm{H}\end{array}$ & $\begin{array}{l}12 \\
M\end{array}$ & $\begin{array}{l}5 \\
\mathrm{~L}\end{array}$ & $\begin{array}{c}18 \\
\mathrm{H}\end{array}$ & $\begin{array}{c}28 \\
\mathrm{H}\end{array}$ \\
\hline $\begin{array}{l}\text { Matthew } \\
\text { (M) }\end{array}$ & $\begin{array}{l}9 \\
M\end{array}$ & $\begin{array}{c}7 \\
H / L\end{array}$ & $\begin{array}{r}10 \\
H / L\end{array}$ & $\begin{array}{l}17 \\
M\end{array}$ & $\begin{array}{l}16 \\
M\end{array}$ & $\begin{array}{c}7 \\
\mathrm{~L} / \mathrm{L}\end{array}$ & $\begin{array}{l}17 \\
M\end{array}$ & $\begin{array}{l}7 \\
M\end{array}$ & $\begin{array}{l}12 \\
M\end{array}$ & $\begin{array}{l}19 \\
M\end{array}$ & $\begin{array}{l}8 \\
M\end{array}$ & $\begin{array}{l}9 \\
M\end{array}$ & $\begin{array}{c}8 \\
M / M\end{array}$ & $\begin{array}{c}44 \\
\mathrm{H}\end{array}$ \\
\hline Ross (L) & $\begin{array}{c}4 \\
M\end{array}$ & $\begin{array}{l}8 \\
8\end{array}$ & $\begin{array}{c}7 \\
\mathrm{M} / \mathrm{L}\end{array}$ & $\begin{array}{l}33 \\
\mathrm{H}\end{array}$ & $\begin{array}{l}5 \\
M\end{array}$ & $\begin{array}{l}11 \\
\mathrm{H}\end{array}$ & $\begin{array}{l}9 \\
M\end{array}$ & $\begin{array}{c}6 \\
H\end{array}$ & $\begin{array}{l}24 \\
M\end{array}$ & $\begin{array}{l}8 \\
\mathrm{H}\end{array}$ & $\begin{array}{c}12 \\
\mathrm{~L}\end{array}$ & $\begin{array}{c}9 \\
M\end{array}$ & $\begin{array}{c}8 \\
M / M\end{array}$ & $\begin{array}{l}31 \\
M\end{array}$ \\
\hline $\begin{array}{c}\text { Average } \\
\text { no. of } \\
\text { words } \\
\text { written } \\
\end{array}$ & 7.67 & 9.83 & 9.6 & 19 & 9.83 & 10.2 & $\begin{array}{c}11.1 \\
7\end{array}$ & 8 & 20.46 & 16.5 & 15.4 & 14.33 & 20.55 & 32 \\
\hline
\end{tabular}

Underlined dates $=$ children have self selected topic

Shaded columns $=$ children have self selected partner

$\mathbf{H}, \mathbf{M}, \mathbf{L}$ underneath child's name in first column refers to their ability

H,M,L (High, middle, low) within the table refers to the ability of the partner they worked with 